\title{
ANALISIS PENURUNAN NASABAH PEMBIAYAAN KPR IB DENGAN AKAD IJARAH MUNTAHIYYAH BITTAMLIK (IMBT) DI BANK SYARIAH XYZ
}

\author{
Reno Virlandana A \\ Universitas Pamulang \\ reno.dkisyariah@gmail.com
}

\begin{abstract}
The Ijarah Muntahiyyah Bit Atamlik (IMBT) contract for KPR IB products at Sharia Bank XYZ from 2008 to 2015 has reached 90\% of the total portfolio financing, but since 2016 to date, financing customers with IMBT contracts have decreased, recorded at the end of December 2019 only 16\% of the total financing. However, the decline in financing customers with the IMBT agreement did not affect the increasing total financing. This study aims to find the causes of the decline in the financing portfolio with the IMBT contract and the policies taken by Sharia Bank XYZ to overcome this decline. Among the results of this research using qualitative methods, it is concluded that the decline in customers with IMBT contracts is caused by internal and external factors. Internal factors are caused by the lengthy on the Internal Rate Return obtained by the bank and the difficulty in increasing the rental margin due to prior customer approval. Meanwhile, external factors are caused by the character of customers who find it difficult to accept if there is an increase in rental margins. From these two factors, Sharia bank XYZ seeks to make policies by reducing and limiting financing products with the IMBT contract and increasing the marketing of financing products with other contracts such as Murabahah or other contracts.
\end{abstract}

Keywords: Declining customer; Ijarah Muntahiyah Bittamlik; Internal and External Factors.

\begin{abstract}
Abstrak
Akad Ijarah Muntahiyah Bit Atamlik (IMBT) untuk produk KPR IB di Bank Syariah XYZ sejak tahun 2008 hingga tahun 2015 mencapai 90\% portofolio dari total pembiayaan, namun sejak tahun 2016 hingga saat ini nasabah pembiayaan dengan akad IMBT semakin menurun tercatat pada akhir Desember 2019 hanya tinggal $16 \%$ dari total pembiayaan. Akan tetapi menurunnya nasabah pembiayaan dengan akad IMBT tersebut tidak berpengaruh terhadap total pembiayaan yang semakin meningkat. Penelitian ini bertujuan mencari penyebab turunnya portofolio pembiayaan dengan akad IMBT dan kebijakan yang diambil Bank Syariah XYZ untuk mengatasi penurunan tersebut. Di antara hasil penelitian dengan metode
\end{abstract}


kualitatif ini menyimpulkan bahwa penurunan nasabah dengan akad IMBT disebabkan oleh faktor internal dan eksternal. Faktor internal disebabkan oleh lamanya tingkat pengembalian Internal Rate Return yang didapat oleh bank dan sulitnya menaikkan margin sewa karena harus ada persetujuan nasabah terlebih dahulu. Sedangkan faktor eksternal disebabkan oleh karakter dari nasabah yang sulit menerima jika ada kenaikan margin sewa. Dari dua faktor tersebut Bank Syariah XYZ mengambil kebijakan dengan mengurangi dan membatasi produk pembiayaan dengan akad IMBT serta meningkatkan pemasaran produk pembiayaan dengan akad lain seperti murabahah atau akad yang lainnya.

Kata Kunci: Penurunan Nasabah; Ijarah Muntahiyah Bittamlik; Faktor Internal dan Eksternal.

\section{PENDAHULUAN}

Bank Syariah adalah badan usaha yang berfungsi sebagai perantara keuangan yang kegiatan utamanya menghimpun dana dari masyarakat dalam bentuk simpanan dan menyalurkan kembali dalam bentuk pembiayaan. Bank Syariah di Indonesia sejak tahun 1992 telah menjadi pilihan dalam sistem perbankan Indonesia. Perbankan Syariah telah diterima secara utuh dalam Sistem Keuangan Indonesia sejak disahkannya Undang-Undang No. 21 tahun 2008 tentang Perbankan Syariah. Dalam Undang-Undang No. 21 tahun 2008 menyatakan semua kegiatan bisnis di Bank Syariah harus tunduk dan patuh pada asas prinsip syariah, prinsip kehati hatian dan demokrasi ekonomi.

Per 30 September 2019 tercatat asset Perbankan Syariah di Indonesia sebesar Rp 503 triliun, dengan keberadaan 202 Bank Syariah dan 2.724 kantor layanan yang tersebar di seluruh wilayah Indonesia. Market Share Perbankan Syariah terhadap Perbankan Nasional mencapai angka 5,94\%. Total pembiayaan dari total aset Bank Syariah sebesar 70,26\% atau Rp 353,94 triliun. Dengan total sebanyak 5,68 juta nasabah. Sementara untuk dana pihak ketiga yang dihimpun mencapai Rp. 398,43 triliyun dengan total sebanyak 31,73 juta nasabah. Produk pembiayaan dengan akad IMBT adalah pembiayaan kepemilikan properti (biasa disebut KPR iB) dan pembiayaan pemilikan kendaraan KPK iB. Karena di Bank Syariah XYZ tidak terdapat produk KKB iB jadi akad IMBT hanya dipakai untuk KPR iB.

KPR iB adalah sejumlah dana yang disediakan oleh Bank Syariah untuk nasabah yang bermaksud ingin memiliki properti atau maksud lainnya yang bersifat konsumtif dengan menggunakan properti sebagai agunan. Adapun properti yang dapat dimiliki dan dapat dijadikan sebagai agunan di antaranya; rumah tapak, rumah toko / rumah kantor dan rumah susun. Semua ini telah diatur dalam Peraturan Bank Indonesia (PBI) No. 18/16/PBI/2016 Tentang Rasio Financing to Value (FTV) untuk Pembiayaan Properti Bank Syariah dan Rasio Loan to Value (LTV) Untuk Kredit Properti Bank Konvesional. Dalam peraturan ini dibahas juga tentang Uang Muka (Down Payment) Untuk Kredit dan Pembiayaan Kendaraan Bermotor. 
Firdaus Muhmmad Arwan (2019) "Al-Ijārah al-Muntahiya bit Al-Tamlik (IMBT) adalah akad sewa menyewa (ijarah) yang diakhiri dengan pemindahan hak kepemilikan barang dari Mu'ajir kepada Musta'jir setelah berakhir masa ijarah melalui jual beli atau hibah. Fatwa DSN MUI Nomor: 27/DSN-MUI/III/2002 tentang Al-Ijarah Al-Muntahiyah bit Al-tamlik mendefinisikan akad IMBT adalah "akad penyediaan dana dalam rangka memindahkan hak guna atau manfaat dari suatu barang atau jasa berdasarkan transaksi sewa dengan opsi pemindahan kepemilikan barang kepada pihak penyewa pada akhir periode sewa".

Sejak berdiri tahun 2004 Bank Syariah XYZ sudah menggunakan akad Ijarah Muntahiyah Bittamlik (IMBT) untuk produk KPR iB. Khusus di kantor cabang syariah Pondok Indah yang baru dibuka pada tahun 2008 hingga tahun 2015 pembiayaan dengan KPR iB dengan akad IMBT ini mencapai $90 \%$ portfolio dari total pembiayaan. Namun pada tahun 2016 hingga saat ini nasabah pembiayaan KPR iB dengan akad IMBT semakin menurun tercatat pada akhir Desember 2019 hanya tinggal $16 \%$ dari total pembiayaan. Akan tetapi, menurunnya jumlah nasabah dan total pembiayaan dengan akad IMBT tidak mempengaruhi jumlah nasabah dan total pembiayaan secara keseluruhan di bank tersebut, justru jumlah nasabah dan total pembiayaan semakin bertambah dan meningkat.

Berdasarkan hal tersebut di atas, untuk mengetahui tentang penyebab dan faktor apa saja yang mempengaruhi penurunan pembiayaan KPR iB dengan akad IMBT maka penulis tertarik melakukan penelitian lebih lanjut agar dapat memberikan informasi dan data untuk dijadikan pedoman bagi management untuk mengambil kebijakan dalam mengatasi penurunan tersebut dengan judul; "Analisis Penurunan Jumlah Nasabah Pembiayaan KPR IB dengan akad Ijarah Mutahiyya Bitamlik (IMBT) di Bank Syariah XYZ”

\section{KERANGKA TEORITIS DAN PENGEMBANGAN HIPOTESIS}

Sebelum penelitian ini dilaksanakan penulis, ada beberapa riset yang telah mengkaji, meneliti dan membuat tulisan mengenai pelaksanaan Ijarah Muntahiya Bitamlik (IMBT). Riset yang dilakukan oleh Mila Sartika \& Hendri Hermawan Adinugraha (2016) dari Universitas Dian Nuswantoro Semarang dengan judul "Implementasi akad Ijarah dan Ijarah Muntahiyya Bitamlik pada Bank BRI Syariah cabang Yogyakarta”. Dari penelitian ini menunjukan bahwa implementasi pembiayaan ijārah dan ijārah muntahiyah bi al-tamlīk pada Bank BRI Syariah tersebut memiliki kesamaan proses dengan pembiayaan murābahah. Kesamaan ini dilihat dari kategori akadnya, yaitu termasuk dalam kategori natural certainty contract, yang notabene akadnya adalah akad jual beli. Adapun Perbedaannya hanya terdapat pada objek/barang yang diperjual-belikan, pada pembiayaan murābahah objeknya hanya berupa barang sedangkan pada IMBT ialah barang dan jasa.

Hasil riset lain yang dilkukan oleh Melina Ernomo (2013) Fakultas Ekonomi dan Bisnis UIN Syarif Hidayatullah Jakarta dengan judul "Analisis Metode Pengakuan Keuntungan Pembiayaan Murabahah Pada PT. Bank Syariah Mandiri". Hasil dari riset ini menyatakan bahwa Bank Syariah Mandiri 
menggunakan metode anuitas dalam mengakui margin / keuntungan pada pembiayaan dengan akad murabahah dan menggunakan kombinasi PSAK 102, PSAK 55 untuk pencatatan akuntansinya.

Hasil riset lain yang dilakukan oleh Ali Muhayatsyah (2019) "Analisis Penerapan Transaksi Ijarah dan Al Ijarah Muntahiyya Bit Tamlik Pada Bank Syariah, mengungkapkan bahwa akad IMBT memberikan keuantungan baik bagi Bank Syariah ataupun nasabah, bagi nasabah sebagai Investasi sedangkan untuk Bank Syariah akad ini mempercepat perputaran uang dan memajukan system investasi yang dinamis.

Dari hasil riset terdahulu di atas masing-masing punya perbedaan permasalahan pada risetnya, dari analisis praktik, metode pengakuan keuntungan, dan implementasi sistem. sedangkan riset yang akan dilakukan peneliti saat ini yakni menganalisis penurunan jumlah nasabah pada produk pembiayaan Ijarah Muntahiyah Bittamlik (IMBT) yang bertujuan untuk mengetahui apa penyebab turunnya jumlah nasabah produk tersebut pada tahun 2015, kebijakan yang diambil, serta strategi yang dijalankan oleh Bank Syariah XYZ dalam mengatasi penurunan produk tersebut.

\section{1) KPR IB dengan akad Ijarah Muntahiya Bittamlik}

Dalam Surat Edaran Otoritas Jasa Keuangan (SEOJK) Nomor 36/SEOJK.03/2015 tanggal 21 Desember 2015, “Tentang Produk dan Aktivitas Bank Syariah dan Unit Usaha Syariah" dalam Lampiran IV halaman 46 sd 48, Memberi penjelasan bahwa pembiayaan dengan akad Ijarah Muntahiya Bittamlik di Bank Syariah adalah "Penyediaan dana dalam rangka memindahkan hak guna atau manfaat dari suatu barang atau jasa berdasarkan transaksi sewa dengan opsi pemindahan kepemilikan barang".

Dalam SEOJK tersebut terdapat 3 poin keunikan karakteristik pembiayaan IMBT di antarannya:

1. "Bank dapat melakukan review ujrah apabila memenuhi syarat sebagai berikut:

a. terjadi perubahan periode akad,

b. terdapat indikasi sangat kuat bahwa apabila tidak dilakukan review akan timbul kerugian bagi salah satu pihak,

c. disepakati oleh kedua belah pihak (Bank dan nasabah)".

2. "Bank dapat meminta nasabah untuk men-jaga keutuhan barang sewa, dan menanggung biaya pemeliharaan barang sewa sesuai dengan kesepakatan. Bank dan nasabah dapat menyepakati cara pembayaran sewa dengan angsuran atau sekaligus".

\section{2) KPR iB Murabahah}

Wahbah AL-Zuhaili (2008), "Murabahah adalah jual beli dengan harga perolehan dan tambahan keuntungan". Dalam Surat Edaran Otoritas Jasa Keuangan (SEOJK) Nomor 36/SEOJK.03/2015, tanggal 21 Desember 2015 "Tentang Produk dan Aktivitas Bank Syariah dan Unit Usaha Syariah" dalam Lampiran IV halaman 56, memberikan penjelasan bahwa Pembiayaan dengan akad Murabahah pada Bank Syariah adalah "Penyediaan dana atau tagihan yang dapat dipersamakan dengan itu untuk transaksi jual beli barang sebesar harga pokok ditambah margin berdasarkan persetujuan atau kesepakatan antara Bank dengan

* Corresponding author's e-mail: reno.dkisyariah@gmail.com 
nasabah yang mewajibkan nasabah untuk melunasi hutang/kewajibannya". KPR iB Murabahah adalah pembiayaan kepemilikan rumah yang menggunakan akad Murabahah.

\section{3) Pengakuan Keuntungan Flat, Efektif dan Anuitas}

Dalam literatur umum Bank Indonesia terdapat 2 (dua) metode perhitungan atau pengakuan keuntungan yang biasa disebut (margin / fee / bagi hasil / bunga) pada transaksi keuangan yaitu flat dan Effektif. Dalam praktiknya terdapat modifikasi yang diterapkan oleh praktisi keuangan seperti metode perhitungan anuitas.

Dewan Syariah Nasional Majelis Ulama Indonesia (DSN-MUI) pada tanggal 21 Desember 2012 menerbitkan Fatwa No. 84/DSN-MUI/XII/2012 tentang "Metode Pengakuan Keuntungan Al-Tamwil Bi Al-Murabahah (Pembiayaan Murabahah) Di Lembaga Keuangan Syariah". Fatwa ini mengatur permasalahan pengakuan keuntungan dengan Metode Proporsional (flat) dan Metode Anuitas. Dalam fatwa tersebut dijelaskan "Metode Proporsional (Thariqah Mubasyirah) adalah pengakuan keuntungan yang dilakukan secara proporsional atas jumlah piutang (harga jual, tsaman) yang berhasil ditagih dengan mengalikan persentase keuntungan terhadap jumlah piutang yang berhasil ditagih (al-atsman almuhashshalah)". Sedangkan, "Metode Anuitas (Thariqah al-Hisab alTanazuliyyah / Thariqah al- Tanaqushiyyah) adalah pengakuan keuntungan yang dilakukan secara proporsional atas jumlah sisa harga pokok yang belum ditagih dengan mengalikan persentase keuntungan terhadap jumlah sisa harga pokok yang belum ditagih (al-atsman al-mutabaqqiyah)'”.

KPR iB yang menggunakan akad IMBT di Bank Syariah XYZ menggunakan metode pengakuan keuntungan secara proporsional / tetap (Thariqah Mubasyirah). Sedangkan KPR iB yang menggunakan akad murabahah menggunakan Metode pengakuan keuntungan secara Anuitas (Thariqah al-Hisab al-Tanazuliyyah / Thariqah al- Tanaqushiyyah).

\section{4) Internal Rate of Return (IRR)}

Ciaran Walsh (2012) menyatakan mengenai Tingkat Laba Internal atau Internal Rate of Return (IRR) adalah "tingkat laba yang membuat nilai sekarang arus kas di masa depan persis menyamakan investasi (awal)". Metode ini menghitung suatu proyek dengan cara menyamakan nilai saat ini (present Value) dari perkiraan arus kas (Cash Flow) dan nilai investasi yang ditanam di awal.

Fungsi IRR dipakai agar kita dapat mengetahui tingkat keuntungan yang didapat dengan menyamakan nilai sekarang investasi (outflow) dengan nilai sekarang penerimaan kas bersih (inflow) di masa depan. Dalam aplikasi Microsoft Excel 2016 bentuk umum dari fungsi IRR adalah: = IRR (range, perkiraan), di mana range menyatakan arus kas. Perkiraan dapat diisi dengan nilai sembarang antara 0 dan 1. Fungsi IRR melakukan perhitungan melalui proses iterasi (mencoba dan mendekati secara berulang). Jika setelah 20 kali penginputan interasi di $M s$ excel belum memperoleh hasil dengan ketelitian 0.0000001, fungsi itu memiliki pesan kesalahan \#NUM. IRR untuk KPR iB dengan angsuran tiap bulannya maka 
harus dikalikan 12 atau disetahun-kan. Fungsi IRR pada KPR iB berubah menjadi; $=\operatorname{IRR}$ (range, perkiraan)*12.

\section{5) Penerapan Ijarah Muntahiya Bittamlik (IMBT) di Bank Syariah XYZ}

Dalam penerapan akad IMBT pada produk KPR iB di Bank Syariah XYZ dapat dilihat dari gambar di bawah ini;

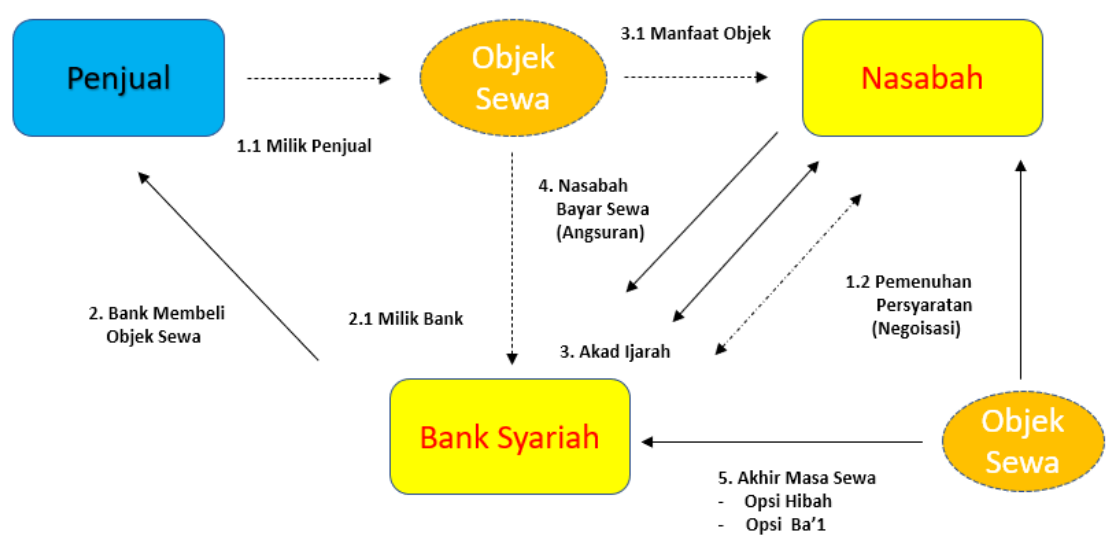

\section{Gambar 1. Teknis Pembiayaan IMBT pada Bank Syariah XYZ}

Dari gambar 1 di atas dapat diterangkan:

1. Kepemilikan

1.1 Milik penjual

1.2 Nasabah datang ke Bank Syariah mengajukan KPR ib untuk pembelian rumah, setelah itu Bank Syariah membeli rumah yang diiginkan nasabah kepada penjual dengan harga yang sudah disepakati antara nasabah dan penjual.

2. Permohonan Pembiayaan Pemilikan Rumah nasabah disetuji Bank Syariah, dan Bank Syariah membeli rumah tersebut kepada penjual sebesar harga yang disepakati antara nasabah dan penjual, bila ada uang muka maka uang muka tersebut disetorkan kepada Bank Syariah

2.1 Rumah tersebut telah menjadi hak milik Bank Syariah

3. Nasabah melaksanakan akad KPR iB dengan prinsip (Ijarah Muntahiyya Bit Tamlik) dengan jangka waktu dan angsuran telah disepakati antara nasabah dan Bank.

3.1 Nasabah menyewa Rumah tersebut kepada Bank Syariah serta nasabah memperoleh manfaat dari menempati rumah yang dibeli.

4. Nasabah membayar angsuran (uang sewa) sesuai jumlah dan jangka waktu yang tercantum dalam akad

5. Pada saat masa sewa berakhir sesuai dengan jangka waktu yang tercantum dalam akad maka bank akan melakukan akad hibah atas rumah tersebut (Bank menghibahkan kepada nasabah) namun jika nasabah memutuskan untuk melakukan pelunasan dipercepat (early repayment) maka Bank Syariah akan 
melakukan akad jual beli dengan harga sesuai dengan sisa sewa saat pelunasan terjadi.

6. Untuk angsuran Bank Syariah XYZ menetapkan angsuran nasabah maksimal $40 \%$ dari gaji yang diterima calon nasabah (sudah termasuk didalamnya hutang hutang lainnya)

\section{METODE RISET}

Jenis riset yang dipakai dalam riset ini adalah survei lapangan (Field Research). Menurut Sumardi Suryabrata (1998) "Penelitian lapangan adalah suatu penelitian yang dilakukan di lingkungan masyarakat tertentu, baik di lembagalembaga organisasi masyarakat (Social), maupun lembaga pemerintah". Riset ini dilakukan penulis dengan mendatangi langsung Bank Syariah XYZ Cabang Pondok Indah sebagai tempat yang dijadikan penelitian. Secara keseluruhan pendekatan riset yang digunakan adalah Empiris, yaitu riset tentang penurunan jumlah nasabah dan total pembiayaan IMBT pada Bank Syariah XYZ Cabang Pondok Indah.

Model riset ini adalah kualitatif, menurut Sumardi Suryabrata (1998). Metode yang digunakan terhadap suatu data yang telah dikumpulkan, kemudian diklasifikasikan, disusun, dijelaskan yakni digambarkan dengan kata-kata atau kalimat yang digunakan untuk memperoleh kesimpulan. Menurut Lexy Moleong (1997) "Metode kualitatif tidak mengadakan penghitungan matematis, statistik dan lain sebagainya, melainkan menggunakan penekanan ilmiah atau penelitian yang menghasilkan penemuan-penemuan yang tidak dapat dicapai dengan menggunakan prosedur-prosedur statistik atau dengan cara-cara lain dari kuantifikasi”. Jika dalam penelitian ini terdapat angka-angka, model perhitungan, dan lain lain yang memiliki keterkaitan dengan kuantitatif, maka penulis melakukan hal ini hanya sebatas untuk memperkuat analisis dan tidak mencari hubungan antara variabel.

Sumber data yang dipakai dalam riset ini adalah data primer dan sekunder. Sumber data primer dalam riset ini adalah data yang didapatkan langsung dari management Bank Syariah XYZ Cabang Pondok Indah, nasabah aktif dan calon nasabah yang mengambil pembiayaan IMBT. Data Sekunder pada riset ini diperoleh melalui buku, artikel, jurnal ilmiah dan sebagainya. berikut:

Dalam riset ini, cara pengumpulan data yang dipakai penulis adalah sebagai

a. Observasi (pengamatan): Untuk mendapatkan data yang dipakai dalam penulisan ini penulis mendatangi langsung kantor Bank Syariah XYZ Cabang Pondok Indah. Observasi yang diamati yaitu proses secara keseluruhan penerapan pembiayaan dengan Ijarah Muntahiyya Bitamlik(IMBT) dan pembiayaan dengan akad alternatif lainnya.

b. Wawancara (Interview): Wawancara dilakukan oleh penulis bertujuan untuk mendapatkan informasi dan data tentang pelaksanaan pembiayaan Ijarah Muntahiyya Bitamlik(IMBT) di Bank Syariah XYZ Cabang Pondok Indah khususnya mengenai proses pembiayaaanya. Penulis melakukan wawancara langsung dengan Pemimpin cabang, Koordinator Relationship 
Manager, Relationsip Manager Consumer Banking, bagian Akad / Administrasi Pembiayaan serta 5 orang nasabah aktif KPR iB yang menggunakan akad IMBT dan 5 orang calon nasabah KPR iB untuk mengetahui pilihan akad apa yang akan dipakai jika pembiayaannya disetujui oleh Bank Syariah XYZ.

c. Dokumentasi: Dokumentasi mengumpulkan data dengan mencermati dokumendokumen yang terdapat pada Bank Syariah XYZ Cabang Pondok Indah. Mulai dari literatur, buku-buku yang ada, dokumen yang menggambarkan sejarah Bank Syariah XYZ Cabang Pondok Indah, dokumen yang menggambarkan struktur Managemen Bank, dokumen yang menerangkan Standar Operasional Perusahaan yang diterapkan pada Bank Syariah, dokumen legal akad pembiayaan pemilikan rumah KPR iB dan laporan data pembiayaan Bank Syariah XYZ Cabang Pondok Indah.

Teknik analisis deskriptif digunakan penulis dalam menganalisis data yang telah dikumpulkan, yaitu dengan cara melukiskan atau menggambarkan keadaan subjek atau objek riset pada saat sekarang berdasarkan fakta-fakta yang ada di lapangan di antaranya; Dokumen Akad dan Surat Persetujuan Permohonan Pembiyaan KPR iB, intisari wawancara dan ketentuan otoritas. Data yang terkumpul juga disusun berdasarkan kerangka berfikir penulis. Gambaran data akan dianalisa secara kritis untuk menghasilkan kesimpulan secara teratur dan rapi serta memberikan solusi.

Semua proses analisis data dalam riset ini dilakukan untuk mengetahui apa saja yang menyebabkan menurunnya jumlah nasabah yang mengambil produk pembiayaan Ijarah Muntahiyya Bitamlik (IMBT) pada tahun 2015 sd 2019 dan kebijakan yang dikeluarkan oleh Bank Syariah XYZ Cabang Pondok Indah untuk menghadapi penurunan tersebut.

\section{ANALISIS DATA DAN PEMBAHASAN}

Seluruh dokumen dan data yang berhasil dikumpulkan akan disusun ulang sehingga tersusun menyatu dalam bab dan sub bab pembahasan. Terkait dengan permintaan Bank Syariah XYZ untuk menjaga kerahasiaan identitas Bank dan pihak-pihak yang menjadi objek wawancara, maka analisa fakta dalam riset ini dibuat dengan tidak mencantumkan identitas Bank Syariah XYZ, Karyawan Bank, identitas diri Nasabah, dan Calon Nasabah.

Hasil dari pengumpulan dan Analisa data, berkas, dokumen dokumen serta wawancara dengan pihak pihak yang sudah ditentukan maka didapat faktor faktor penyebab penurunan nasabah pembiayaan pemilikan rumah (KPR iB) dengan akad IMBT adalah sebagai berikut:

\section{Faktor Internal}

Adanya kebijakan 4 kebijakan internal Bank Syariah XYZ yang sangat mempengarui pembiayaan KPR iB dengan akad IMBT di antaranya:

1. Menggunakan sistem perhitungan Margin Effektif untuk KPR iB dengan akad IMBT

2. Penyesuaian Margin / ujroh untuk KPR iB dengan akad IMBT

3. Addendum akad IMBT dan di Konversi ke akad murabahah 
4. Mengutamakan pemasaran produk KPR iB dengan akad Murabahah yang menggunakan system perhitungan margin Anuitas.

\section{Faktor Ekternal}

1. Kurangnya pengetahuan nasabah tentang pelaksanaan akad IMBT

2. Tidak adanya kesepakatan dengan nasabah jika terjadi peninjauan Margin / ujroh.

3. Umumnya nasabah melakukan pelunasan dipercepat.

\section{Faktor Internal}

\section{Menggunakan sistem perhitungan Margin Effektif untuk KPR iB dengan akad IMBT.}

Kebijakan ini dibuat agar Bank dapat membukukan bagi hasil lebih cepat di awal masa periode pembiayaan namun metode ini mempengaruhi nilai angsuran setiap bulan. Selama ini KPR iB di Bank Syariah XYZ mengunakan sistem perhitungan Flat dengan angsuran setiap bulan bernilai sama/tetap baik pokok pembiayan serta Margin untuk lebih jelasnya dapat diliat dari ilustrasi di bawah ini: Tuan A mengajukan KPR iB dengan akad IMBT sebesar Rp. 150.000.000 dengan Tenor 10 tahun dengan tingkat Margin sewa $9 \%$ setara Effektif dan Anuitas $14.51 \%$.

Tabel 1

Perbandingan tabel angsuran Flat dan Effektif serta IRR.

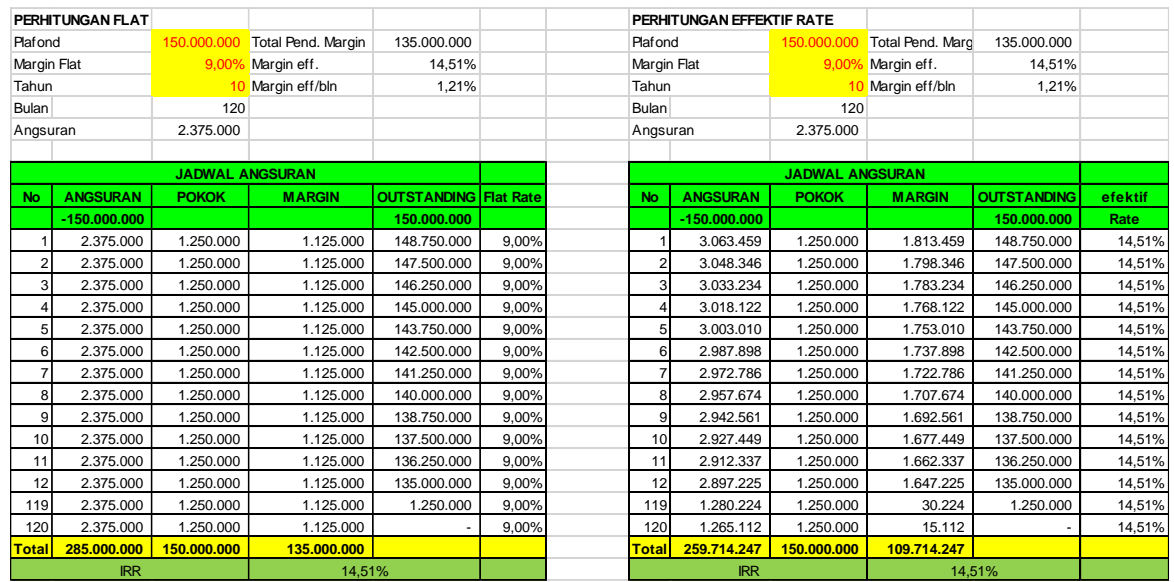

Dari tabel 1 di atas dapat dilihat perbandingan model angsuran Flat dan Effektif dengan penjelasan di bawah ini:

a. Jumlah angsuran di awal lebih besar dengan system Effektif dengan Rp.3.063.459 sementara dengan system Flat sebesar Rp. 2.375.000, sehingga mempengarui DSR (Debt to Service Ratio) nasabah / tingkat penghasilan nasabah dibanding pembiayaan yang didapat dari Bank. Jadi semakin tinggi angsuran maka semakin tinggi pula penghasilan yang harus dimiliki nasabah.

b. Total margin yang bisa dibukukan oleh Bank Syariah XYZ di awal jauh lebih besar dengan system angsuran Effektif sebesar Rp. 1.813.469 sedangkan Sistem Flat murni sebesar Rp. 1.125.000, walaupun secata total Margin yang didapat Effektif jauh lebih kecil dibanding Flat Murni. Kebijakan ini diambil Bank 
Syariah XYZ karena pengalaman dan pada umum nya nasabah KPR iB IMBT melunasi pembiayaannya sebelum jatuh tempo bahkan sebelum 50\% jangka waktu pembiayaan berjalan. Selain itu pertimbangkan kuntitatif menggunakan Internal Rate of Return juga menunjukan perbedaan yang signifikan, untuk lebih jelasnya, dapat melihat ilustrasi pada tabel di bawah ini:

\section{Tabel 2. Simulasi jika Pembiayaan Dilunaskan Setelah 1 tahun (12 Bulan) dengan System Flat dan Effektif}

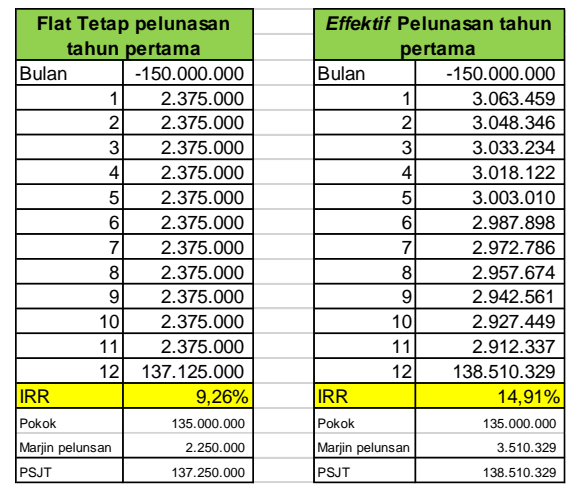

Dari tabel 1 dapat dijelaskan bahwa secara total IRR kedua system perhitungan margin sama di angka $14.51 \%$ jika pembiayaan berjalan sampai lunas / jatuh tempo 10 tahun (120 bulan), namun pada table 2 saat pelunasan dipercepat atau nasabah melunasi setelah masa 1 tahun pembiayaan dapat dilihat pada table 2 maka IRR Sistem Flat Tetap sebesar 9.26\% sedangkan IRR Sistem Effektif 14.91\%. di mana pada saat pelunasan dipercepat Bank Syariah XYZ mengenakan 3x pembayaran margin bulan berjalan. Hal inilah yang menjadi dasar Bank Syariah $\mathrm{XYZ}$ membuat kebijakan tersebut.

\section{Penyesuaian Margin Sewa / Ujroh KPR iB dengan akad IMBT untuk pembiayaan yang masih berjalan.}

Kebijakan ini dibuat untuk nasabah KPR iB yang sudah aktif dan bank Syariah XYZ ingin menjalankan Klausula Offering Later dan Akad Perjanjian pembiayaan IMBT yang berbunyi " angsuran dapat ditinjau secara berkala, apabila ada perubahan maka dapat disepakati secara Bersama” namun di sini ada kata kata "disepakati secara bersama" yang dapat dijelaskan bahwa setiap ada perubahan angsuran maka harus ada kesepakan antara Bank Syariah XYZ dan Nasabah, bila tidak ada kesepakatan maka kenaikan angsuran tidak dapat dilaksanakan. Ini juga sesuai dengan karakteristik yang ada dalam SEOJK Nomor 36/SEOJK.03/2015 tanggal 21 Desember 2015. Ini kebijakan yang sulit dilaksanakan karena berhubungan dengan pihak nasabah Bank Syariah XYZ yang cenderung resisten terhadap penyesuaian margin sewa/ujoh. Sampai tulisan ini dibuat hanya ada 10 nasabah yang sepakat dari semua nasabah yang mendapatkan surat pengajuan penyesuaian margin sewa. 


\section{Addendum akad IMBT dan dikonversi ke akad murabahah}

Kebijakan ini dibuat oleh Bank Syariah XYZ dalam upaya memaksimalkan pendapatan Margin sewa dan mempercepat pemenuhan IRR nya, namun kebijakan ini tidak mudah dijalankan karena kembali harus meminta persetujuan nasabah sesuai dengan perjanjian pembiayaan IMBT dan umumnya nasabah menolak kebijakan ini karena pasti angsuran bulanan nasabah akan mengalami kenaikan. Bila dilihat lebih lanjut kebijakan ini berpotensi melanggar prinsip Syariah dalam pelaksanaannya.

\section{Mengutamakan pemasaran produk KPR iB dengan akad Murabahah yang menggunakan system perhitungan margin Anuitas.}

Di bank Syariah XYZ Produk KPR iB selain dengan akad IMBT juga terdapat produk KPR iB dengan akad Murabahah di mana selama ini akad Murabahah jarang dipasarkan oleh pemasaran. Produk KPR iB dengan Akad Murabahah dapat menggunakan sistem perhitungan margin Anuitas di mana angsuran perbulan tetap tetapi komposisi pembagian antara Pokok dan marginnya selalu berubah tiap bulan, di awal bulan angsuran system ini akan mengenakan angsuran Margin jauh lebih besar sehingga IRR bank lebih cepat terpenuhi. Inilah yang dikatakan angsuran dengan model piramida terbalik Untuk lebih jelasnya kita dapat melihat tabel di bawah ini (dengan menggunakan ilustrasi kasus poin A):

Tabel 3

Tabel Angsuran KPR iB akad Murabahah dengan Metode Angsuran Effektif serta IRR.

\begin{tabular}{|c|c|c|c|c|c|}
\hline \multicolumn{3}{|c|}{ PERHITUNGAN ANUITAS } & & & \\
\hline \multicolumn{2}{|c|}{ Plafond } & 150.000 .000 & Total Pend. Margin & 135.000 .000 & \\
\hline \multicolumn{2}{|c|}{ Margin Flat } & $9,00 \%$ & Margin eff. & $14,51 \%$ & \\
\hline \multicolumn{2}{|l|}{ Tahun } & 10 & Margin eff/bln & $1,21 \%$ & \\
\hline \multicolumn{2}{|l|}{ Bulan } & 120 & & & \\
\hline \multicolumn{2}{|c|}{ Angsuran } & 2.375 .000 & & & \\
\hline \multicolumn{5}{|c|}{ JADWAL ANGSURAN } & \\
\hline \multirow[t]{2}{*}{ No } & ANGSURAN & POKOK & MARGIN & OUTSTANDING & efektif \\
\hline & -150.000 .000 & & & 150.000 .000 & Rate \\
\hline 1 & 2.375 .000 & 561.541 & 1.813 .459 & 149.438 .459 & $14,51 \%$ \\
\hline 2 & 2.375 .000 & 568.330 & 1.806 .670 & 148.870 .128 & $14,51 \%$ \\
\hline 3 & 2.375 .000 & 575.201 & 1.799 .799 & 148.294 .927 & $14,51 \%$ \\
\hline 4 & 2.375 .000 & 582.155 & 1.792 .845 & 147.712 .772 & $14,51 \%$ \\
\hline 5 & 2.375 .000 & 589.193 & 1.785 .807 & 147.123 .579 & $14,51 \%$ \\
\hline 6 & 2.375 .000 & 596.317 & 1.778 .683 & 146.527 .262 & $14,51 \%$ \\
\hline 7 & 2.375 .000 & 603.526 & 1.771 .474 & 145.923 .736 & $14,51 \%$ \\
\hline 8 & 2.375 .000 & 610.822 & 1.764 .178 & 145.312 .914 & $14,51 \%$ \\
\hline 9 & 2.375 .000 & 618.207 & 1.756 .793 & 144.694 .707 & $14,51 \%$ \\
\hline 10 & 2.375 .000 & 625.681 & 1.749 .319 & 144.069 .026 & $14,51 \%$ \\
\hline 11 & 2.375 .000 & 633.245 & 1.741 .755 & 143.435 .781 & $14,51 \%$ \\
\hline 12 & 2.375 .000 & 640.901 & 1.734 .099 & 142.794 .880 & $14,51 \%$ \\
\hline 119 & 2.375 .000 & 2.318 .599 & 56.401 & 2.346 .630 & $14,51 \%$ \\
\hline 120 & 2.375 .000 & 2.346 .630 & 28.370 & 0 & $14,51 \%$ \\
\hline Total & 285.000 .000 & 150.000 .000 & 135.000 .000 & & \\
\hline \multicolumn{3}{|c|}{ IRR } & \multicolumn{2}{|c|}{$14.51 \%$} & \\
\hline
\end{tabular}

Dari tabel 1 dan 3 dapat dilihat dengan sistem anuitas total angsuran sama dengan sistem Flat namun komposisi angsuran pokok dan marginnya berbeda seperti piramida terbalik, angsuran margin lebih besar di awal dan sebaiknya untuk angsuran pokok, sedangkan untuk IRR totalnya sama dengan sistem Flat Murni. Perbedaanya akan nampak apabila nasabah melunasi sebelum jatuh tempo maka 
IRR dengan metode anuitas jauh lebih besar, untuk lebih jelasnya dapat dilihat pada tabel di bawah ini:

\section{Tabel 4. Simulasi jika Pembiayaan Dilunaskan Setelah 1 tahun (12 Bulan) dengan System Flat Rate, Effektif dan Anuitas}

\begin{tabular}{|r|r|}
\hline \multicolumn{2}{|c|}{$\begin{array}{c}\text { Flat Tetap pelunasan } \\
\text { tahun pertama }\end{array}$} \\
\hline Bulan & -150.000 .000 \\
\hline 1 & 2.375 .000 \\
\hline 2 & 2.375 .000 \\
\hline 3 & 2.375 .000 \\
\hline 4 & 2.375 .000 \\
\hline 5 & 2.375 .000 \\
\hline 6 & 2.375 .000 \\
\hline 7 & 2.375 .000 \\
\hline 8 & 2.375 .000 \\
\hline 9 & 2.375 .000 \\
\hline 10 & 2.375 .000 \\
\hline 11 & 2.375 .000 \\
\hline & 137.125 .000 \\
\hline & $9,26 \%$ \\
\hline IRR & 135.000 .000 \\
\hline Pokok & 2.250 .000 \\
\hline Marjin pelunsan & 137.250 .000 \\
\hline PSJT & \\
\hline
\end{tabular}

\begin{tabular}{|c|c|}
\hline \multicolumn{2}{|c|}{$\begin{array}{c}\text { Effektif Pelunasan tahun } \\
\text { pertama }\end{array}$} \\
\hline Bulan & -150.000 .000 \\
\hline 1 & 3.063 .459 \\
\hline 2 & 3.048 .346 \\
\hline 3 & 3.033 .234 \\
\hline 4 & 3.018 .122 \\
\hline 5 & 3.003 .010 \\
\hline 6 & 2.987 .898 \\
\hline 7 & 2.972 .786 \\
\hline 8 & 2.957 .674 \\
\hline 9 & 2.942 .561 \\
\hline 10 & 2.927 .449 \\
\hline 11 & 2.912 .337 \\
\hline 12 & 138.510 .329 \\
\hline IRR & $14,91 \%$ \\
\hline Pokok & 135.000 .000 \\
\hline Marjin pelunsan & 3.510 .329 \\
\hline PSJT & 138.510 .329 \\
\hline
\end{tabular}

\begin{tabular}{|c|c|}
\hline \multicolumn{2}{|c|}{$\begin{array}{c}\text { Anuitas pelunasan tahun } \\
\text { pertama }\end{array}$} \\
\hline Bulan & -150.000 .000 \\
\hline 1 & 2.375 .000 \\
\hline 2 & 2.375 .000 \\
\hline 3 & 2.375 .000 \\
\hline 4 & 2.375 .000 \\
\hline 5 & 2.375 .000 \\
\hline 6 & 2.375 .000 \\
\hline 7 & 2.375 .000 \\
\hline 8 & 2.375 .000 \\
\hline 9 & 2.375 .000 \\
\hline 10 & 2.375 .000 \\
\hline 11 & 2.375 .000 \\
\hline 12 & 149.692 .347 \\
\hline IRR & $17,35 \%$ \\
\hline Pokok & 147.950 .311 \\
\hline Marjin pelunsan & 5.155 .431 \\
\hline PSJT & 153.105 .743 \\
\hline
\end{tabular}

Dari tabel 4 di atas dapat kita lihat bahwa KPR iB akad Murabahah dengan system perhitungan margin Anuitas lebih menguntungkan jika nasabah melunasi pembiayaanya lebih cepat/ sebelum jatuh tempo di mana IRR dengan sistem anuitas sebesar $17.35 \%$ sedangkan sistem Effektif sebesar $14.91 \%$ dan Flat Rate sebesar 9.26\% di mana ketentuan Bank Syariah XYZ apabila pelunasan dipercepat / sebelum jatuh tempo dikenakan pembayaran 3x margin bulan berjalan.

Selain itu juga dengan tidak mengutamakan pemasaran produk KPR Ib dengan akad IMBT secara otomatis akan mengurangi nasabah pengguna akad tersebut. Hal ini sejalan dengan penelitian yang dilakukan oleh Hesti Yunda Purna lestari dan Rizal Magnadi (2017) "Pemasaran dan promosi adalah faktor utama terhadap keputusan pengambilan pembiayaan"

\section{Faktor Eksternal}

\section{Kurangnya pengetahuan nasabah tentang pelaksanaan akad IMBT.}

Umumnya nasabah tidak terlalu faham dengan akad IMBT serta pelaksanaannya karena sudah senang pembiayaannya sudah disetujui dan direalisasikan, namun ketika ditanya tentang akad IMBT umumnya menjawab "saya sudah beli rumah dengan cicilan di Bank Syariah dan Rumah tersebut di jadikan jaminan oleh bank Syariah serta rumah tersebut sudah menjadi milik saya" (Hasil wawancara nasabah) seperti bank umum lainnya. Pada pelaksanaan hakikatnya rumah tersebut belumlah menjadi milik nasabah, tetapi masih milik bank syariah hingga jangka waktu yang ditetapkan di akad dan status nasabah adalah sebagai penyewa di mana angsuran nasabah dianggap sebagai nilai sewa perbulannya. Saat status nasabah sebagai penyewa maka bank sebagai pemilik rumah bisa untuk menaikan harga sewa rumah tersebut. Rumah akan menjadi milik 
nasabah saat jangka waktu sewa selesai dengan proses akta hibah dari bank. Sehingga nasabah yang faham tdak akan memilih akad ini karena mereka ingin kepastian dan ingin yang angsuran tidak berubah sejak awal hingga jatuh tempo pembiayaan.

Hal ini sesuai dengan penelitan yang dilakukan oleh Diah Wahyuningsih, CS. Titik dan H. Oktaviani (2014), "Mayoritas nasabah pembiayaan di Bank Syariah mandiri tidak memahami konsep akad syariah dan hanya memahami sebatas konsep system bunga dan bagi hasil saja"

\section{Tidak adanya kesepakatan dengan nasabah jika terjadi peninjauan Margin / ujroh oleh Bank Syariah.}

Hal manusiawi dan umum jika seseorang merasa dirugikan dalam sebuah kesepakatan pasti tidak akan pernah setuju dengan kesepakatan tersebut. Inilah yang menjadi karakteristik akad IMBT Bank bisa merubah angsuran di tengah perjalanan tapi dengan persetujuan nasabah terlebih dahulu. Ketika Bank Syariah XYZ ingin menaikkan angsuran sewa dan nasabah merasa dirugikan dengan kenaikan tersebut maka tidak akan tercapai sebuah kesepakatan dan Bank Syariah XYZ tidak akan bisa menaikkan angsuran tersebut secara sepihak. Jika bank Syariah XYZ menaikkan sepihak tanpa persetujuan nasabah akan terjadi pelanggaran akad dan secara syariah akad tersebut batal demi hukum. Disini menunjukan penelitian yang dilakukan Hanudin amin (2019). Prilaku konsumen KPR Ib dengan akan IMBT tidak selalu berdasarkan akad Syariah semata, namun tetap realistis terhadap faktor keuntungan adalah benar dan terbukti.

\section{Umumnya nasabah melakukan pelunasan sebelum jatuh tempo.}

Sebagian nasabah jangka waktu yang dipilih untuk pembiayaan adalah yang terlama karena menyangkut kemampuan mengangsurnya, semakin lama jangka waktu pembiayaan seseorang maka semakin kecil angsurannya, semakin kecil angsurannya maka semakin kecil pula besaran gaji yang dibutuhkan untuk menjadi pemasukan nasabah yang bisa disetujui untuk menerima pembiayaan dengan plafond yang diinginkan nasabah. Di dalam perjalanan sebelum jatuh tempo pembiyaan nasabah ada yang mengalami kenaikan gaji, mendapatkan bonus, atau memiliki usaha lain sehingga nasabah memiliki dana dan tabungan yang cukup untuk pelunasan jatuh tempo. Pelunasan sebelum jatuh tempo ini diperbolehkan dalam skema pembiayaan KPR iB dengan akad IMBT dan untuk pemindahan kepemilikannya menggunakan opsi jual beli (Bank menjual rumah miliknya dengan harga sesuai sisa pokok dan margin bulan berjalan). Di Bank Syariah XYZ hampir semua nasabah melunasi sebelum jatuh tempo sehingga sulit untuk Bank Syariah XYZ mengejar IRR/pendapatan bank yang lebih tinggi.

\section{KESIMPULAN DAN SARAN}

Dari hasil analisa data dan pembahasan yang telah penulis jabarkan maka kesimpulan yang dapat diambil sebagai penyebab penurunan nasabah KPR iB dengan akad IMBT dai Bank Syariah XYZ adalah:

* Corresponding author's e-mail: reno.dkisyariah@gmail.com 
1. Kebijakan yang dibuat oleh manajemen dengan merubah system perhitungan margin menjadi effektif secara otomatis akan menurunkan tingkat Debt to Saving Ratio (kemampuan nasabah dalam mengangsur) dengan sendirinya calon nasabah memilih untuk tidak memakai fasilitas pembiayaan KPR iB dengan akad IMBT karena akan mendapatkan nilai pembiayaan yang lebih kecil dibanding dengan fasilitas KPR iB dengan akad Murabahah yang mendapatkan fasilitas pembiayaan yang lebih besar dengan tingkat Debt to Saving Ratio (kemampuan nasabah dalam mengangsur) yang sama.

2. Selain itu Akad IMBT angsurannya dapat berubah setiap saat walaupun harus dengan persetujuan nasabah, hal ini yang membuat nasabah berada dalam ketidakpastian, berbeda dengan akad Murabahah yang sesuai dengan karakteristik akadnya nasabah mendapatkan kepastian angsuran tanpa ada perubahan disepanjang jangka waktu pembiayaan berlangsung.

3. Kebijakan manajemen dengan membatasi pemasaran produk KPR iB dengan akad IMBT secara otomatis akan menurunnya nasabah yang mengetahui produk yang memakai akad IMBT dan beralih dengan produk sejenis lain yang dipasarakan yaitu KPR iB dengan akad Murabahah sehingga porto folio nasabah pembiayaan KPR iB dengan menggunakan akad IMBT akan habis dengan sendirinya.

Saran dari penulis untuk manajemen Bank Syariah XYZ agar mempertimbangkan kembali untuk mengurangi pemasaran produk pembiayaan KPR iB dengan akad IMBT, karena dengan karakteristik yang dimilikinya dapat mengakomodir kebutuhan pembiayaan bagi nasabah yang tidak dapat dipenuhi oleh akad lainnya seperti refinancing (pembiayaan kembali). Jadi alangkah baiknya Bank Syariah XYZ menyediakan semua produk dengan bermacam akad Untuk masalah sistem angsuran dan kenaikan angsuran pada masa pembiayaan sebaiknya pihak Bank Syariah XYZ dan nasabah bisa membuat kesepakatan sejak awal pembiayaan dan dituangkan dalam akad IMBT nya, sehingga pada saat kenaikan tidak perlu lagi meminta persetujuan nasabah tapi Bank Syariah XYZ hanya tinggal mengirimkan surat pemberitahuan kepada nasabah.dengan cara ini bank Syariah dapat kembali meningkatkan portofolio akad IMBT pada produk KPR IB nya.

\section{DAFTAR PUSTAKA}

H. Amin, H. (2019). The Islamic theory of consumer behaviour for ijarah home financing. Journal of Asia Business Studies.

Al-Zuhaili, Wahbah. (2008). Al-Fiqh Al-islami Wa Adillatuhu, Juz 4. Damaskus. Dar Fikr al-Mu'asir.

Arwan, F. M. (2020). IJARAH MUNTAHIYAH BITTAMLIK SEBAGAI KONSTRUKSI PERJANJIAN SEWA BELI. Millah: Jurnal Studi Agama, 19(1), 23-50. 
Lestari, H. Y. P., \& Magnadi, R. H. (2017). Analisis faktor-faktor yang berpengaruh terhadap Keputusan Nasabah untuk mengambil pembiayaan pada BMT Al Halim Temanggung. Diponegoro Journal of Management, 6(1), 177-187.

Moleong, Lexy.J. (2006), Metode Penelitian Kualitatif, edisi revisi. Bandung. PT Remaja Rosda Karya.

Ernomo, M. (2013). Analisis Metode Pengakuan Keuntungan Pembiayaan Murabahah Pada PT. Bank Syariah Mandiri.

Mila Sartika \& Hendri Hermawan Adinugraha (2016) "Implementasi akad Ijarah dan Ijarah Muntahiyya Bitamlik pada Bank BRI Syariah cabang Yogyakarta”, Fakultas Syariah, Semarang, Perpustakaan Universitas Dian Nuswantoro.

Muhayatsyah, A. (2019). Analisis Penerapan Transaksi Ijarah Dan Al Ijarah Al Muntahiya Bit Tamlik Pada Bank Syariah. Jurnal Ekonomi Syariah, Akuntansi Dan Perbankan (JESKaPe), 3(2), 1-18.

Otoritas Jasa Keuangan. (2016). Standar Produk Murabahah. www.ojk.go.id Jakarta

Otoritas Jasa Keuangan. (2016). Standar Produk Ijarah Mutahiyya Bitamlik. www.ojk.go.id Jakarta

Sabiq, Sayyid. (2008). Fiqhus Sunnah. Penerjemah Asep Sobari, Muhil Dhofir, Sofwan Abbas \& Amir Hamzah. Jakarta. Al-I'tishom Cahaya Umat.

Sumardi Suryabrata (1998), Metodologi Penelitian, Jakarta: PT Raja Grafindo Persada, Cet.ke-2

Wahyuningsih D, Titik CS \& Oktavianti H. (2014). Analisis Prilaku Nasabah dalam Pembiayaan di Bank Syariah Mandiri. Media Trend. Vol. 9 No.1 Maret 2014 Hal 90 - 114.

Walsh, Ciaran. (2012). Key Management Ratios Edisi Keempat. Penerjemah Agus Dharma. Jakarta. Esensi Erlangga Group. 